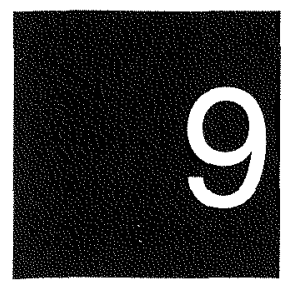

\title{
Common property regimes in Aboriginal Australia: totemism revisited
}

\author{
Deborah Bird Rose
}

In the closing years of the twentieth century, debates in Australia about Indigenous institutions of common property ownership and management are inseparable from the highly political issues of Native Title. In this chapter I intend to move beyond debates about the politics of land tenure and toward an analysis of a dynamic jurisprudence of duty in which responsibilities and rights are considered together. I will examine totemism as a common property institution for long-term ecological management. The purpose is to describe and analyse this Indigenous regime in order to examine some of the principles which inform it. The implications of this analysis speak to the sustainability of life on this arid continent.

The fundamental divide in debates about common property has been whether common property is to be understood as an absence of institutions for the management of territory and resources, or whether common property is to be understood as a type of communal management (Berkes and Farvar 1989:7, Eythorsson 1995:7, Maurstad 1995). Thanks to Hardin's 'tragedy of the commons' article, debates about common property make a vital link between systems of ownership and systems of management. It is now established that there are many forms of common property institutions for management of resources including those of land and sea. The terms 'resource' and 'regime' can 
be used to distinguish between the resource itself and the set of institutions (or absence of institutions) by which it is held and managed (Berkes and Farvar 1989:9). In many parts of the world common property institutions are not officially recognised by formal legal institutions. Several regimes may coexist, and common property regimes may be hidden from or invisible to formal institutions; coexistence may be complementary or contradictory (Maurstad 1995). The coexistence of different property regimes frequently correlates with the coexistence of different forms of production and different productive groups (for example, Berkes et al. 1989, Berkes 1989).

\section{Common property concepts in Australia}

Hunter-gatherer peoples, perhaps more than any others, have been until very recently disregarded as land and resource owners and managers. Only within the last fifteen years have questions of land management emerged as a key component of research with Indigenous people in Australia (Williams and Hunn 1982). The long historical silence on these issues is connected with the settler view that Aboriginal people were parasites on nature. Elkin (1954:15) gave the mark of scientific authority to this view in a book first published in 1938

The food-gathering life is parasitical; the Aborigines are absolutely dependent on what nature produces without any practical assistance on their part.

This view of parasitism was intricately connected to the view of terra nullius. The idea that the land was untransformed led directly to the idea that land was unowned. Locke's famous statement on property and ownership could have been written precisely to justify the dispossession of Indigenous peoples in the European settlement of Australia

Whatsoever then he moves out of the state that Nature hath provided and left it in he hath mixed his labour with and thereby makes it his property (quoted in Shiva 1993:25).

The reversal of the parasite view dates to Rhys Jones's (1969) work on the use of fire as a tool of land management. He called this system fire-stick farming, and his use of the term 'farming' was deliberate (Jones 1995). It was provocative precisely because it hit a cultural/ political nerve. It indicates that, like farmers, Aboriginal people intervened in their ecosystems to transform them in predictable, and to them desirable, ways. They consciously managed their ecosystems 
for long-term objectives that included the long-term productivity of the land and the long-term fertility of resources. There has been a degree of debate about Jones's analysis, and there are still some adherents to the parasite view, but the evidence is quite clear that Aboriginal people managed resources in definable and observable ways in order to produce long-term productivity in their environments (for example, Bowman 1995; Latz 1995b).

The official view that Indigenous people did not own the land at the time of European conquest has been overturned by the High Court's 'Mabo' decision (1992) which gave formal legal recognition to the fact that at the time of conquest Indigenous people did own the land. In theory, Indigenous people continue to exercise rights of ownership-now labelled 'Native Title' - except in areas where conquest and appropriation have formally extinguished those rights. The more recent Native Title Act (Commonwealth 1993) provides a legislative framework within which the continuity of Native Title can be asserted, and the High Court's recent 'Wik' decision (1996) provides further articulation of how Native Title can be understood legally to survive. Where Native Title continues to exist, land cannot be alienated from Indigenous use and management without negotiation with the Indigenous title holders. It is likely that cooperative management agreements will increase as the Native Title Act begins to have a greater impact.

Issues of Indigenous land tenure have thus acquired a special urgency in Australia. The analysis of common property regimes brings to these issues a vital perspective: that usufructuary rights are embedded within regimes of responsibility, and that regimes of rights and regimes of management are inseparable. Without rights, resources will not be managed; without management, resources will be degraded and depleted, and rights will become meaningless.

If there are Indigenous regimes of common property ownership and management, what institutional forms do they take? How might they be discerned? In what ways can they be understood to be systems that are produced through time, rather than just the fortuitous outcomes of actions performed by individuals? There can be no single answers to these questions, but I believe that an instructive start can be made by considering totemism as an institution for the management of common property resources. In addition, an examination of the history of anthropological and philosophical analysis of totemism also helps explain why serious consideration of common property regimes has been so long delayed. 


\section{Land tenure and common property regimes}

Aboriginal cultures across Australia (with the possible exception of some urban people who have been severed from their homelands for generations) construct identity, social relations, and spirituality in relation to local place. In Aboriginal English the term is 'country'. Economic, social and cultural development is articulated most profoundly and productively in the context of country. The Australian continent prior to conquest was articulated as a cultural landscape through the conjunction of local countries (for example, see Peterson and Long 1986). Countries related to each other regionally through marriage, trade, ritual relationships (summarised in Rose 1996). Across the continent articulations of countries were accomplished through major trade systems and the extensive 'Dreaming tracks' which are the travels of creative beings, impressed upon the landscape and told, sung, and performed in contexts of ritual (Mulvaney 1976).

Countries were (in most areas still are) associated with social groups in a reflexive relationship of ownership and belonging. The social organisation of landowning groups has been debated with vigour for decades by anthropologists, and in recent years the Aboriginal Land Commissioner has conducted inquiries into traditional ownership under the Land Rights Act (NT) 1976 which have enabled Aboriginal people to place their views into the debate. Local land-based groups, recruited though descent, are generally called clans by anthropologists, and the term has moved into Aboriginal and other Australian English vernaculars. Clans are linked into larger clusters, with those sharing a language are often referred to in the non-technical literature as tribes. Clans are also linked through marriage ties, trade relationships, shared responsibilities in religious ceremonies, and alliances for war-terms like community, tribe, and nation have been used by different observers to refer to clusters of clans that interact on a regular basis. In many areas the devastating loss of population brought about by colonisation has resulted in people's primary identity being framed at the level of 'tribe' or 'community' rather than at the level of a fragmented and devastated clan structure. ${ }^{1}$

Debate has focused on the composition of the clan (patrilineal, cognatic, or some other form of recruitment), and about which level of organisation-clan or larger community-is best considered to be a landowning group (Gumbert 1984 provides a useful summary for the 
non-specialist). The Land Rights Act (NT) 1976 defines Aboriginal traditional owners (section 3[1]) as

a local descent group of Aboriginals who have common spiritual affiliations to a site on the land, being affiliations that place the group under a primary spiritual responsibility for that site and for the land, and who are entitled by Aboriginal tradition to forage over that land.

It thus designates the local group ('clan') as the landowning group, focuses on spiritual responsibilities, and treats foraging (use-rights) almost as an afterthought. And it is something of a blessing that foraging is not central because in twenty years of land claims it has been shown conclusively that rights to forage are not restricted to local groups such as clans. On all the evidence, use-rights in respect of resources are not restricted to, or best articulated through, small groups such as clans (see Ingold 1987 for a pointed discussion of this issue).

In contrast to the Northern Territory legislation, the Native Title Act 1993 speaks primarily to the right to forage: "The expression "native title" or "native title rights and interests" means the communal, group or individual rights and interests of Aboriginal peoples or Torres Strait Islanders in relation to land or waters (233.[1]); and "rights and interests" includes 'hunting, gathering or fishing rights and interests' (233.[2]). Clearly the framers of this Act had usufructuary rights in mind.

Indigenous philosophies assert that social life is most properly directed toward ensuring that the past and present of a people and their country be brought into the future. Continuity is a key value (Stanner 1979). To return, therefore, to my original point about the inseparability of regimes of rights and regimes of responsibilities, my contention is that these Native Title rights and interests are not parasitical-they include not only the right to take resources, but also the responsibility to ensure that resources will be there in the future. Totemism appears to constitute just such a jurisprudence of responsibility and right.

\section{Intellectual history}

'Totemism' was one of the cornerstones of emergent social science and related disciplines around the turn of the century. Sir James Frazer's Totemism and Exogamy (four volumes, 1910) and Freud's Totem and 
Taboo (1918) testify to the grasp of 'totemism' on the minds of these key thinkers. Debated regularly from decade to decade, totemism has become a palimpsest of western social theories. I will not linger in the history of thought concerning totemism, but rather will summarise extensively in order to elucidate some of the assumptions that have hindered an understanding of totemism in the material world, and thus have hindered an understanding of Indigenous common property regirnes.

Definitions of totemism vary enormously, as I will discuss, but at the core the phenomenon labelled totemism posits a non-random relationship between particular humans and particular non-humans. It is this human/non-human link that exercised the thinking of early theorists such as Frazer (1910) and Freud (1918) (discussed in Levi-Strauss 1963:2-3). I believe that we must consider that this project, of distinguishing civilisation from savagery, and culture from nature, was given special urgency by the pressure placed on key concepts of western thought under the intellectual revolution taking place in conjunction with secularisation and Darwinian theory. A key feature of western thought since the Enlightenment, the disjunction between nature and culture, was powerfully threatened by evolutionary theory, for if humans are descended from animals, where is the boundary between them?

Hayden White (1978) has shown that these boundary questions become urgent when concepts of humanity are threatened. Totemism filled a wonderfully useful role in providing an answer to the question that was not explicitly being asked. The question was that of boundary maintenance. The answer was that if civilisation is marked by separation of culture from nature, it follows that a religious outlook which posited a relationship between culture and nature must be understood as an absence of civilisation, and must therefore constitute an evolutionary stage at which humans were not fully separated from nature. Analysis of totemism could thus confirm the superiority of western civilisation and the inferiority of the savage, defining and ordering their difference, while simultaneously linking them together as moments in a global history of progress. As Stanley Diamond asserts of anthropology

We study men, that is, we reflect on ourselves studying others, because we must, because man in civilisation is the problem...The questions we bring to history come out of our own need. The task of anthropology is to clarify these questions (Diamond 1974:100). 
In 1912 Durkheim wrote that 'the totem is before all a symbol, a material expression of something else. But of what?' He would go on to assert that the totem is a symbol of god and of society, brought together, in his view, in the clan (quoted in Lessa and Voigt 1979:34). Subsequent social scientists did not devote works specifically to totemism, probably as a result of a number of critiques which cast doubt on the view that totemism constituted an analytically discrete phenomenon (discussed in Levi-Strauss 1963). Nevertheless, the question 'a symbol of what?' provided an opportunity for people to inscribe their particular theories of society and culture on the tabula of totemism.

Malinowski, for example, accepted the first part of Durkheim's assertion-that a totem is a symbol of something else. In good economic fashion, he found a consumption value: 'the road from the wilderness to the savage's belly and consequently his mind is very short', he wrote in 1948, 'and for him the world is an indiscriminate background against which there stand out the useful, primarily the edible, species of plant and animal' (Malinowski 1948:44). He would go on to characterise Australian Aboriginal totemism as the most 'elementary' form, and would note that totemic cults had as their purpose the provisioning of abundance (Malinowski 1948:46). He was thus able to draw Aboriginal Australians into his general theory of science, magic and religion. Magic, he contended, is a set of techniques used by people to effect control of nature to their own ends when their practical knowledge and technology are inadequate (Malinowski 1948:19, 29). Radcliffe-Brown developed this view in more elegant manner, suggesting it was a common characteristic of hunting peoples to elaborate a major food item. While Radcliffe-Brown would initiate analysis into the logical properties of totems, both he and Malinowski are expressive of the theory, stated so succinctly by Levi-Strauss, that totems are 'good to eat' (1963:62).

Levi-Strauss himself found another meaning in totemism. In his view, totemism answers a universal question of the mind: 'how to make opposition, instead of being an obstacle to integration, serve rather to produce it.' Natural species, he claims, are chosen because they are good to think, not because they are good to eat' (1963:89). Rather than positing a one-to-one correspondence, Levi-Strauss looks to contrasting relationships between totems, and rather than considering that totems index the world, he held that they articulate the mind. 
Levi-Strauss's work only makes sense if one accepts as universal a number of dichotomies that have been characteristic of western thought since the Enlightenment, and that have been subjected to a range of excellent critiques (for example, Young 1990).

- mind vs body this dichotomy promotes the view that totems can be good to eat or good to think but not good both to eat and to think. Reading this dichotomy back into Malinowski's work, we see that he inscribes savagery in that short distance between the savage belly and the savage mind. The lack of mind/body split is held to be characteristic of savages, and by implication, to differentiate them from civilised man.

- culture vs nature this dichotomy promotes the view that culture is more evolved to the extent that it distinguishes itself from nature. Reading this dichotomy back into Malinowski, the distance between the wilderness and the savage is an index of savagery itself, differentiating that state from civilisation.

- difference is oppositional Levi-Strauss talks about 'opposition' when he quite clearly means difference, and he takes it as given that difference is oppositional and is in need of transformation. He further presupposes that integration is a desirable social goal in and of itself. Such a view generates its own paradox. On the one hand it seeks to close the distance between savagery and civilisation by claiming universalities of mind. On the other hand, it oppresses those who find that they are socially positioned as different from those who are socially positioned as not-different, for it indicates that they/we are problems to be overcome. As Diamond so succinctly adverts, 'man in civilisation is the problem' (1974:100).

\section{Dreaming ecology}

Thus far I have looked at unifying and universalising theories of totemism. I now turn to the Australian context. Data from Aboriginal Australia, especially that compiled by Spencer and Gillen (1899) were drawn on by all the early theorists of totemism and 'primitive' religion. Subsequently, most of the critiques of attempts to generate unified theories of totemism were supported with evidence from Australia. Thus, virtually every major proposition concerning totemism was supported in part by reference to Australian data. At the same time, 
virtually every critique of attempts to universalise was also supported with reference to Australian data. As Levi-Strauss indicates throughout his study, although not with this intention, every general theory can be both supported by, and contradicted with, evidence from Aboriginal Australia.

Anthropology in Australia has not sought unified global theories, but rather sought to analyse specific instances of totemic organisation, action, and thought. Lloyd Warner's pioneering ethnography of 1939 A Black Civilisation, based on research he conducted in the 1920s, signals in its title the author's distance from the oppressive savagerycivilisation dichotomy. Warner stated that the totemic system of northeast Arnhem Land was 'highly elaborated and permeates all the activities of the group and all of its concepts of life in the world about it' (Warner 1969:378). He found it to be a system of ritual relations between clan members and certain species of plants and animals. Totemism in north east Arnhem Land, Warner contended, 'is intelligible only in terms of the social organisation, the relation of the technological system to society generally, and the ideas which surround the society's adjustment to the natural environment' (Warner 1969:234).

In light of Warner's emphasis on both the religious quality of totemism and its pervasive, indeed foundation, relation to religion, society and the environment, it seems odd that decades were to pass before these ideas were reformulated in other parts of the continent.

In the early 1960 s Stanner took a phenomenological approach to totemism and religion, emphasising the mystical quality of totemism (1979 [1962]). He also linked totems with clans and with country, asserting that the group has a corporate title that covers not only the country or site, and a mystical relation to the totemic creators, but also non-material property associated with the country (Stanner 1965:13).

Stanner's study was closely followed by T.G.H. Strehlow's study of Aboriginal religion in Central Australia. He documents a totemic landscape in its social, spiritual and geographical complexity. He uses the term 'totems' to refer to the creative beings ('totemic ancestors') who made the world ${ }^{2}$

Because the whole landscape of Central Australia was studded with a multitude of sacred sites where supernatural beings had lived and moved and gone to rest, and because these sacred sites were in turn linked by an interesting network of mythological trails left behind by these supernatural beings, every tribal subgroup area... was filled with a large number of sacred sites associated with a diversity of totems (Strehlow 1978:26). 
Briefly but tantalisingly he proceeded to discuss some of the ritual which ensured the continuance of each totemic species or other existent. Primarily, however, Strehlow was seeking to draw out the religious or spiritual significance of totemic religion and to bring it into dialogue with contemporary spiritual concerns. In a later study, which I discuss shortly, he turned his analysis more closely to resources and land tenure.

In the same time frame Worsley's (1967) study of totemism, derived from his Groote Eylandt research, followed the tradition of Malinowski in seeking to distinguish totemism from logic and science. Like Malinowski, he shows that non-Western people do possess systems of logic, classification, and explanation which can be loosely equated with western science ('proto-scientific' in Worsley's terminology [1967: 154]). Totemism is distinguished from science, he concludes, by its lack of system; it is 'agglomerative, arbitrary and fortuitous' (Worsley 1967:151). Peterson (1972) follows on from Durkheim, Stanner and Strehlow in examining totemism as a link between person, group and country. He found totemism to be a mechanism for ordering sentiment toward home place, and thus to be a key mechanism in territorial spacing (see also Strehlow 1970).

Ted Strehlow's 1970 article 'Geography and the Totemic Landscape in Central Australia' marks a major turning point. His foundational assumption was that while totems can and do represent many things, they also, perhaps centrally, are themselves. Strehlow thus brings the material world into the analysis in a way that previous scholars, with the exception of Warner, had not done. Like others, Strehlow agreed that the totem and the clan are connected to each other and to an area of land (this was Stanner's point too), and he went on to look to the organisation of ritual life oriented toward sustaining the life of the species, and other totems. Each clan, according to Strehlow's analysis of Aranda societies, is associated with a number of totemic beings, with one of which the clan is most intimately associated and for which it bears a central responsibility. Ancestral tracks, or the Dreaming tracks of these beings link groups along the way

...each Aranda local group was believed to perform an indispensable economic service not only for itself but for the population around its borders as well. Thus, the Eastern Aranda Purula-Kamara local group of Ujitja was believed to have the responsibility of creating rain for the whole of the surrounding countryside by the performance of the Ujitja rain ceremonies. Other Aranda rain totemic clans...were credited with performing identical services for the populations in their local areas. In 
the same way, the members of kangaroo, euro, emu, carpet snake, grass seed, and other totemic clans were regarded as having the power of bringing about the increase of their totemic plants or animals not only within their local group areas, but throughout the adjoining regions as well (Strehlow 1970:102).

The remainder of this pivotal article is devoted to issues of authority (see Rowse 1992). Strehlow laid out the relevant data for ecological analysis, but chose to proceed in another direction. Thus, it was possible for a 1979 textbook on cultural anthropology that took a deliberately ecological approach to assert that 'since, as far as I know, no one has investigated the ecological functions of totemism...it is impossible to assess the ecological relevance of Australian totemism' (Kottak 1979:201).

Newsome's 1980 study of the Dreaming track of the red kangaroo in Central Australia initiated the work of analysing the ecological relevance of Australian totemism. This sacred track traverses some of the toughest desert country in the world, and the sacred sites coincide with the most favoured areas for kangaroos. In particular, there is a strong correlation between Red Kangaroo Dreaming sites, and the permanent waters which are the sources of fresh herbage during drought. The red kangaroo relies on fresh green herbage; after rains the animals forage widely, but in drought they must rely on restricted areas. As the sites are protected, so too are the kangaroos at these sites. These are places to which living things retreat during periods of stress, and from which they expand outward again during periods of plenty. Clearly, opportunistic predation at these sites, especially during periods of stress (when humans, too, are stressed), would have longterm negative effects on red kangaroos and other species.

Aboriginal people in this part of the world approach a sacred sites with a respect that includes forbearing to hunt. Spears are left at a distance, and the caretaking of the site is accomplished without interfering with the red kangaroos whose site and refuge it is. Peter Latz, a botanist who has carried out extensive work in Central Australia, notes that the most sacred/protected places are likely to be places where a number of Dreamings meet up or cross over. He describes them this way

...there's a lot of dreaming trails which cross over, these are really important places. They are so sacred you can't kill animals or even pick plants. And of course you don't burn them. You might burn around them in order to look after them (Latz 1995a:70). 
Not only in Central Australia, but across the whole continent, there are similar structures of restraint, management for long-term productivity, control of sanctuaries, protection of permanent waters, refugia, breeding sites, and of certain plant communities. As well, there is shared responsibility (Rose 1996). Responsibilities appear to lie with the local group in the first instance, but ritual life extends and develops these responsibilities. In land claims held under the Northern Territory Act, claimants in ecological zones from desert to semi-arid savannas to coasts and islands assert that they can only fulfil their responsibilities to their country with the help of various categories of kin.

While the right to forage is widespread, the responsibilities that go with that right differ depending on one's relationship to the country: a major difference is whether it is one's father's country or one's mother's country. For example, in parts of Arnhem Land, men cannot visit the sacred/dangerous sites in their father's country without the men for whom it is their mother's country. They have to make gifts to the matrifiliates, and only matrifiliates can take food and water from the area (Peterson 1972:19). In parts of the Victoria River country (NT), to give another example, patrifiliates are responsible for burning the country; matrifiliates are responsible for organising the burning, and if the patrifiliates burn badly or wrongly they are accountable to matrifiliates who will punish them (see also Bradley 1995). Thus, in many areas it is simply not possible for the patrifiliates of a country to fulfil their obligations without the complementary cooperation of other kin, and in many land claims the claimants have asserted that the patrifiliates and the matrifiliates are all owners of the country as Aboriginal law defines 'ownership'.

A system of complementarity is part of a system for organising of difference in the service of producing interdependence. Difference is organised to be complementary rather than oppositional, and thus is constitutive of cultural, social and ecological life rather than, as LeviStrauss suggests, an obstacle to be overcome. The result is that individuals and groups hold sets of a complementarity of responsibilities at numerous local and regional levels. The broad complex of responsibilities well matches the rights people have of harvesting and consuming resources both locally and regionally.

Responsibilities, like rights, are differentiated in structure but not necessarily in substance. Both are held and exercised across spiritual, social and ecological domains. Indeed, it is a western convention to 
separate the spiritual, the social, and the ecological. Indigenous people hold these domains as integral parts of the long-term management of life on earth.

\section{Conclusions}

It is now possible to begin to look afresh at totemism as a common property institution. To do so we must set aside the oppressive dichotomies that Levi-Strauss's work highlighted. We must, for a start, propose that subsistence activity and intellectual activity are not necessarily dichotomous or opposing activities. We must ask whether difference might not be a desired characteristic rather than a problem to be resolved, and we must learn to consider interdependence. We must start to look at difference played out not only in the local but also in regional frames. Finally, we must not allow the study of ritual to eclipse the analysis of ecological pragmatics.

The questions I have broached in this chapter are points of departure for analysis which I hope will be carried further in numerous contexts. I conclude with highlighting some of the major implications.

Responsibilities are differentiated and complementary. They are held and exercised both locally and regionally. It follows that no country is self-sufficient. The people of each country depend on others for the proper management of the relationships which sustain them all, and each group depends on others for the very pragmatic practices of land management. The burning, the preservation of species, the preservation of permanent waters: these constitute a sample of the responsibilities which are carried out at the local level, but which have regional implications.

Restraint is equally part of this system. There are sanctuaries where people do not hunt or fish or gather, and places where burning is done with extra caution or not at all. There are responsibilities based on totemic relationships: the kangaroo people can forbid others to kill and eat kangaroo, for example. As a general rule, totems are linked to taboos that enforce restraint and that are managed by the appropriate people.

Differentiated and complementary responsibilities sustain regional interdependencies. There are few hard and fast boundaries, but rather strong ecological, social and spiritual links that are reproduced through the generations. Further, as Strehlow said, to promote the well-being of that which is your responsibility is good not just for you 
but for others in your region. Restraint from hunting, eating, and burning, for example has wide implications. Proper exercise of responsibilities benefits other species as well as broad systems. The use of fire is the best pragmatic example of symbiotic action toward systemic productivity in time and space (see Rose 1996).

What this means to issues of ownership is thus quite different to Hardin's original proposition. While Hardin contended that private ownership would be the key to responsible land management, an analysis of Aboriginal systems suggests that responsible land management is best accomplished through systems of interpenetrating rights and responsibilities. In this type of Aboriginal system, self-interest is constructed to stand in linked and complementary fashion to the self-interest of other people, groups, species, and ecological systems. In this system, living beings truly stand or fall together. Self-interest is thus accomplished through promoting the interests of others as well as one's own.

The High Court's Mabo and Wik decisions, and the Native Title Act, all point in this direction-toward coexisting property regimes, including common property regimes. While some sectoral interests hold that regimes of exclusivity are essential to the full maximisation of their purposes, evidence drawn more broadly from ecological and social analysis indicates that co-management is likely to have longterm advantages for the survival of ecosystems and species, including the human species. Native Title thus constitutes a unique opportunity for the Australian nation to develop long-term strategies for the survival of life on this arid continent.

\section{Notes}

1. It is impossible to know what Aboriginal Australia was like prior to invasion, although there are numerous techniques for reconstructing models of probability. I am assuming a multilayered set of identifications among families in these kin-based societies, but it is by no means certain that all Aboriginal people once were organised into clans, or that clans, if they existed, were organised along one model of descent to the exclusion of others.

2. Often referred to as Dreaming or Dreamtime ancestors. 


\section{References}

Aboriginal Land Rights (NT) Act 1976 (Cwth).

Berkes, F, 1989. 'Cooperation from the Perspective of Human

Ecology', in F. Berkes, ed., Common Property Resources: ecology and community-based sustainable development, Belhaven Press, London:70-88.

Berkes, F. and M. Farvar, 1989. 'Introduction and Overview', in F. Berkes, ed., Common Property Resources: ecology and community-based sustainable development, Belhaven Press, London:1-18.

Berkes, F., D. Feeny, B. McCay and J. Acheson, 1989. "The benefits of the commons', Nature 340:91-3.

Berndt, R. (ed.), 1970. Australian Aboriginal Anthropology, University of Western Australia Press, Nedlands.

Bowman, D., 1995. 'Why the skillful use of fire is critical for the management of biodiversity in Northern Australia', in D. Rose (ed.), Country in Flames: proceedings of the 1994 symposium on biodiversity and fire in North Australia, Biodiversity Unit, Department of the Environment, Sport and Territories, and the North Australia Research Unit, Canberra and Darwin:103-110.

Bradley, J., 1995. 'Fire: emotion and politics; A Yanyuwa case study' in D. Rose (ed.), Country in Flames: proceedings of the 1994 symposium on biodiversity and fire in North Australia, Biodiversity Unit, Department of the Environment, Sport and Territories, and the North Australia Research Unit, Canberra and Darwin:25-31.

Diamond, S., 1974. In Search of the Primitive: a critique of civilisation, Transaction Books, New Brunswick, NJ.

Elkin, A., 1954 [1938]. The Australian Aborigines: how to understand them, Angus and Robertson, Sydney.

Eythorsson, E., 1995. 'Who should have a voice in management of local marine resources: some comments on the common property debate and the design of co-management institutions for northNorwegian fjords fisheries', paper prepared for the 5th Common Property Conference of the International Association for the Study of Common Property, May 24-26, Bodo, Norway, unpublished.

Frazer, J., 1910. Totemism and Exogamy: a treatise on certain early forms of superstition and society, 4 vols, Macmillan, London.

Freud, S., 1918. Totem and Taboo: resemblances between the psychic life of savages and neurotics, Moffat Yard and Co., New York. 
Gumbert, M., 1984. Neither Justice Nor Reason: a legal and anthropological analysis of Aboriginal land rights, University of Queensland Press, St Lucia.

Ingold, T., 1987. The appropriation of nature: essays on human ecology and social relations, Manchester University Press, Manchester.

Jones, R., 1969. 'Fire-stick Farming', Australian Natural History $16(7): 224-8$.

1995. 'Mindjongork: legacy of the firestick,' in D. Rose (ed.), Country in Flames; Proceedings of the 1994 symposium on biodiversity and fire in North Australia, Biodiversity Unit, Department of the Environment, Sport and Territories, and the North Australia Research Unit, Canberra and Darwin:11-18.

Kottak, C., 1979. Cultural Anthropology, Random House, New York.

Latz, P., 1995a. Bushfires and Bushtucker: aboriginal plant use in Central Australia, Institute of Aboriginal Development Press, Alice Springs.

— 1995b. 'Fire in the desert: increasing biodiversity in the short term, decreasing it in the long term,' in D. Rose (ed.), Country in Flames; Proceedings of the 1994 symposium on biodiversity and fire in North Australia, Biodiversity Unit, Department of the Environment, Sport and Territories, and the North Australia Research Unit, Canberra and Darwin:77-86.

Leach, E. (ed.), 1967. The Structural Study of Myth and Totemism, Tavistock, London.

Lessa, W. and Voigt, E. 1979. Reader in Comparative Religion: an anthropological approach, Harper and Row, Publishers, New York.

Levi-Strauss, C., 1963. Totemism, Beacon Press, Boston.

Malinowski, B., 1948. Magic, Science and Religion, and Other Essays, Souvenir Press, London.

Maurstad, A., 1995. Customs in court, Paper prepared for the 5th Common Property Conference of the International Association for the Study of Common Property, May 24-26, Bodo, Norway, unpublished.

Mulvaney, D., 1976. "The Chain of Connection": the material evidence' in N. Peterson (ed.), Tribes and Boundaries in Australia, Australian Institute for Aboriginal Studies, Canberra:72-94.

Native Title Act 1993 (Cwth).

Newsome, A., 1980. 'The eco-mythology of the Red Kangaroo in Central Australia,' Mankind 12(4):327-34.

Peterson, N., 1972. 'Totemism yesterday: sentiment and local organisation among the Australian Aborigines', Man 7(1):12-32. 
and J. Long, 1986. Australian Territorial Organization, Oceania Monograph 30, University of Sydney, Sydney.

Rose, D., 1996. Nourishing Terrains: Australian Aboriginal views of landscape and wilderness, Australian Heritage Commission, Canberra.

Rowse, T., 1992. 'Strehlow's Strap: functionalism and historicism in colonial ethnography,' in B. Attwood and J. Arnold (eds), Power, Knowledge and Aborigines, Journal of Australian Studies, La Trobe University Press, La Trobe:88-103.

Shiva, V., 1993 'Reductionism and Regeneration: a crisis in science' in

M. Meis and V. Shiva (eds), Ecofeminism, Spinifex Press,

Melbourne:22-35.

Spencer, B. and F. Gillen, 1968 [1898]. The Native Tribes of Central Australia, Dover Publications, New York.

Stanner, W., 1979. White Man Got No Dreaming: essays 1938-73, Australian National University Press, Canberra.

- 1965. 'Aboriginal territorial organization: estate, range, domain and regime', Oceania 36(1):1-26.

Strehlow, T., 1970. 'Geography and the totemic landscape in central Australia: a functional study', in R. Berndt (ed.), Australian Aboriginal Anthropology, University of Western Australia Press, Nedlands:92-140.

- 1978 [1964]. Central Australian Religion: personal monototemism in a polytotemic community, Special Studies in Religions, V. 2, Australian Association for the Study of Religions, Bedford Park, SA.

The Wik Peoples $v$ the State of Queensland $\mathcal{E}$ Ors.

Warner, L., 1969 [1937]. A Black Civilisation: a social study of an Australian tribe, Peter Smith, Gloucester, Mass.

White, Hayden, 1978. Tropics of Discourse: essays in cultural criticism, Johns Hopkins University Press, Baltimore.

Williams, N. and E. Hunn, 1982 Resource Managers: North American and Australian hunter-gatherers, Australian Institute of Aboriginal Studies, Canberra.

Worsley, P., 1967. 'Groote Eylandt totemism and Le Totemisme Aujourdhui, in E. Leach (ed.), The Structural Study of Myth and Totemism, Tavistock, London:141-60.

Young, R., 1990. White Mythologies: writing history and the West, Routledge, London. 